\title{
Immune Response Profiling of Patients with Anogenital Warts
}

\author{
${ }^{1}$ Manjula Singh, ${ }^{2}$ Deepshi Thakral, ${ }^{3}$ Hemanta K Kar, ${ }^{4}$ Narayan Rishi, ${ }^{5}$ Dipendra K Mitra
}

\section{ABSTRACT}

The incidence of anogenital warts, commonly caused by human papillomavirus (HPV-6 and HPV-11), is increasing worldwide. These infections are frequently associated with relapse, possibly due to weak host immunity. However, the role of cell-mediated immune players in combating infection is not clearly understood till date. Here, we attempted to understand the immune profile among patients with anogenital warts. In this study, we compared the T-helper cell (Th1 and Th2) response in patients with venereal warts due to HPV-6 and HPV-11 infection relative to healthy controls (HCs) in vitro. In the in vitro model, the peripheral blood mononuclear cells were stimulated with HPV peptide 6 or 11, stained for T-cell surface marker and intracellular cytokines (interferon [IFN]- $\square$ and interleukin [IL]-4), and were analyzed by flow cytometry. In the present study, significant decrease was observed in the frequency of IFN- $\square$ T cells as compared with HCs. On the contrary, frequency of T cells expressing IL-4 was significantly increased in the patients. The observed functional skewing of HPV-specific T cells from Th1 to Th2 response in patients indicated suppressed immunity against the HPVs. Findings of our study have potential in the near future for strategizing adjunct immunomodulation approaches with the standard treatment for early remission and prevention of recurrence.

Keywords: Human papillomavirus, Interferon gamma, Interleukin-4, Venereal warts.

How to cite this article: Singh M, Thakral D, Kar HK, Rishi N, Mitra DK. Immune Response Profiling of Patients with Anogenital Warts. Indian J Med Biochem 2017;21(1):11-16.

\section{Source of support: Nil}

Conflict of interest: None

${ }^{1}$ Scientist D, ${ }^{2}$ Research Scientist II, ${ }^{3}$ Senior Consultant and Former Director, ${ }^{4}$ Advisor ${ }^{5}$ Professor and Head

${ }^{1}$ Department of Epidemiology and Communicable Diseases Indian Council of Medical Research, New Delhi, India

2,5Department of Transplant Immunology and Immunogenetics All India Institute of Medical Sciences, New Delhi, India

${ }^{3}$ Department of Dermatology, Max Superspeciality Hospital; Dr. Ram Manohar Lohia Hospital, New Delhi, India

${ }^{4}$ Amity Institute of Virology and Immunology, Amity University Noida, Uttar Pradesh, India

Corresponding Author: Dipendra K Mitra, Professor and Head Department of Transplant Immunology and Immunogenetics All India Institute of Medical Sciences, New Delhi, India, Phone: +911126594638, e-mail: salilmitra2@gmail.com

\section{INTRODUCTION}

The incidence of viral sexually transmitted infections (STIs) has shown an upward trend worldwide. ${ }^{1}$ Condyloma acuminata (anogenital warts) are one of the commonest STIs caused by human papillomaviruses (HPVs), ${ }^{2}$ primarily by HPV-6 and HPV-11 (in 90\% of cases) ) $^{3-6}$ and occasionally by HPV-16 and HPV-18. ${ }^{7,8}$ Warts are generally papillomatous lesions occurring on the mucus membrane or skin of the external genitalia as well as in the perianal region. Patients are not generally satisfied with the standard treatment of warts because of high recurrence rate caused due to persistence of HPV in normal-presenting adjacent skin, ${ }^{9}$ adding to the difficulty of the physicians. For successful treatment outcome, a more comprehensive understanding of the host immune response and its interaction with HPV is necessary. Detailed understanding of the host immune mechanism will lead to better clinical management in the future. Few studies have reported suppression of local immune response mediated by dysfunctional natural killer (NK) cells, dysfunctional Langerhans cells, and resultant T-helper cells skewing toward Th2 phenotype at the local disease site. ${ }^{10-12}$ The Langerhans cells in HPV-infected lesions appeared in clumps with altered distribution and morphology ${ }^{13,14}$ and no surface expression of maturation marker CD83. ${ }^{15}$ It has been found that proportion of T-regulatory cell correlated with the size of the warts. Studies have also reported reduced interleukin (IL)-10 and transforming growth factor (TGF)$\square 1$ expression and increased interferon (IFN)- $\square$ and IL-2 expression in small-sized warts. ${ }^{16}$ In addition, the serum levels of IL- 6 were increased and IFN- $\square$ were decreased in HPV-infected patients. ${ }^{17}$ All these findings suggested an immune imbalance in patients with HPV-infected genital warts. The aim of this study was to understand how HPV antigen (6 and 11)-specific immune responses in peripheral blood of patients with venereal warts are related. Here we tried to assess T-helper cell response in vitro on stimulation with HPV-6 and - 11 antigens both in patients and in controls, as well as IFN- $\square$ and IL-4 response to detect skewing of T-helper cell to decreased cellular immunity. We demonstrated functional skewing of HPV antigen-specific T-helper cell response in these patients that may have future implications in treatment strategies to boost protective immune response. 


\section{MATERIALS AND METHODS}

\section{Patient Selection}

A total of 67 subjects ( 56 males, 11 females with age range from 18 to 64 years) with venereal warts for an average period of 5 months [minimum 1 month and maximum 15 months of duration, human immunodeficiency virus (HIV) negative without having any other immunosuppressive disease or having any history of treatment with immunosuppressive drugs in past or present or a history of skin warts] and a total of 26 age- and sex-matched healthy controls (HCs) with no clinical evidence or history of any viral warts were also recruited from the outpatient Department of Dermatology and Venereology at Dr Ram Manohar Lohia Hospital, New Delhi.

\section{Sample Collection and Peripheral Blood Mononuclear Cell Isolation}

After obtaining duly signed informed consent form, detailed history and findings were recorded as per the pro forma from both experimental and control subjects. Peripheral venous blood $(8-10 \mathrm{~mL})$ was collected in heparinized tubes, from the enrolled patients and controls. The patients under the study were provided standard treatment regimen of the disease. We isolated peripheral blood mononuclear cells (PBMCs) by Ficoll density gradient (Lymphoprep, Oslo, Norway) and cultured in RPMI 1640 medium which contained $10 \%$ fetal bovine serum supplemented with antimycotic agents and antibiotics.

\section{In vitro Stimulation of Peripheral Blood Mononuclear Cells}

The PBMCs $\left(2 \times 10^{6}\right.$ cells $\left./ \mathrm{mL}\right)$ from each experimental and control subject were cultured with recombinant HPV-6 and HPV-11 peptide (Genxbio) in separate wells for 24 hours at $37^{\circ} \mathrm{C}$ in $5 \% \mathrm{CO}_{2}$ incubator $[10 \mu \mathrm{g} / \mathrm{mL}$ brefeldin A/Golgi transport blocker (Sigma) was added to the culture]. Unstimulated PBMCs were used as negative control and fluorescent minus one control was also included. All the samples were further processed for cell surface and intracellular staining with titrated antibody dose.

\section{Staining for Cell Surface Markers and Intracellular Cytokines}

Cells were stained with fluorescent conjugated antibodies including $\square$-CD3 PE-Cy5 (eBiosciences, CA, USA) followed by intracellular staining with $\square$-IFN- $\square$-fluorescein isothiocyanate and $\square$-IL-4 PE (eBiosciences, CA, USA) by standard protocol. We used $2 \%$ paraformaldehyde for sample fixation prior to acquisition.

\section{Flow Cytometry and Data Analysis}

Stained cells were acquired on FC500 (Beckman Coulter) and Listmode raw cytometer data files were analyzed by the in-built CXP analysis STATA version 14.2. Lymphocytes were gated on forward and side scatter, and CD3 T cells were evaluated for IFN- $\square$ or IL-4 positivity. We determined \% frequency of CD3+IFN- $\square+$ and CD3+IL-4+ $\mathrm{T}$ cells in comparison to unstimulated control.

\section{Statistical Analysis}

Statistical analysis was performed by nonparametric two-tailed Student's t-test for paired samples with STATA version $14.2 \mathrm{p}$-value less than 0.05 was taken as statistically significant.

\section{OBSERVATIONS}

In this study, we recruited 67 patients with anogenital warts. The number of warts at presentation varied from 1 to more than 50 in some patients. The size varied from 1 to $30 \mathrm{~mm}$. The site of venereal warts in males was primarily penile shaft, glans penis, prepuce, perianal, gluteal, and buttocks, while labia majora and minora, vulva, perineal and perianal region were affected in females. Peptide-specific (HPV-6 and -11) Th1 and Th2 immune responses were determined in anogenital wart patients and HCs. After stimulation of PBMCs obtained from study subjects (SSs) and HCs with HPV-6 and HPV-11 peptide, cells were immunofluorescently stained with antibodies against T-cell surface marker (CD3) along with anti-IFN- $\square$ (Th1 cytokine) and antiIL-4 (Th2 cytokine). The mean percent frequency of HPV-6 peptide-stimulated T cells expressing IFN- $\square$ was $0.26 \pm 0.18$ in wart patients and $0.53 \pm 0.75$ in HCs (Graph 1A). The statistically significant $\mathrm{p}$-value between the two groups was 0.008 . On the contrary, the mean percent frequency of HPV-6 peptide-stimulated T cells expressing IL-4 of $0.65 \pm 0.55$ in the wart patients was significantly higher $(\mathrm{p}=0.0001)$ than those of HCs $(0.18$ \pm 0.1 ) (Graph 1B). Furthermore, similar pattern of HPV antigen-specific T-cell immune response was observed after stimulation with HPV-11 peptide. As observed with HPV-6 peptide stimulation, the mean percent frequency of HPV-11 peptide-stimulated T cells expressing IFN- $\square$ was decreased with a value of 0.27 (standard deviation $[S D] \pm 0.23$ ) in subjects with warts in contrast to 0.43 (SD \pm 0.5 ) in HCs (Graph 2A) with a significance of $p=0.04$ (Graph 2A). Consistent significant increase in the mean percent frequency of HPV-11 peptide-stimulated T cells expressing IL-4 was observed $(p=0.001)$ in subjects with wart with mean value of $0.68(\mathrm{SD} \pm 0.7)$ than with mean value of $0.2(\mathrm{SD} \pm 0.2)$ in $\mathrm{HCs}$ (Graph 2B). 


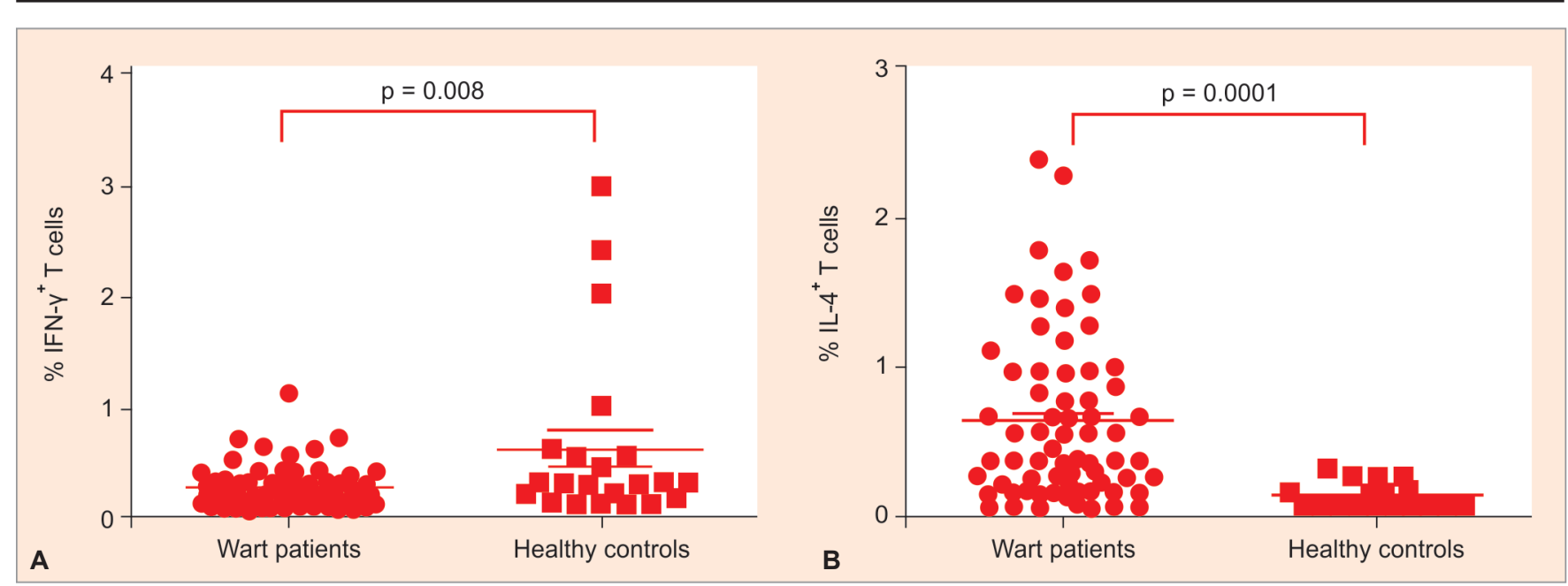

Graphs 1A and B: T-cell response against HPV-6 peptide in wart patients and HCs. Data are shown as scatter plot of percent frequency and mean of: (A) CD3+IFN- $\square+$ T cells; and (B) CD3+IL-4+ T cells; p-valve $<0.05$ was considered significant

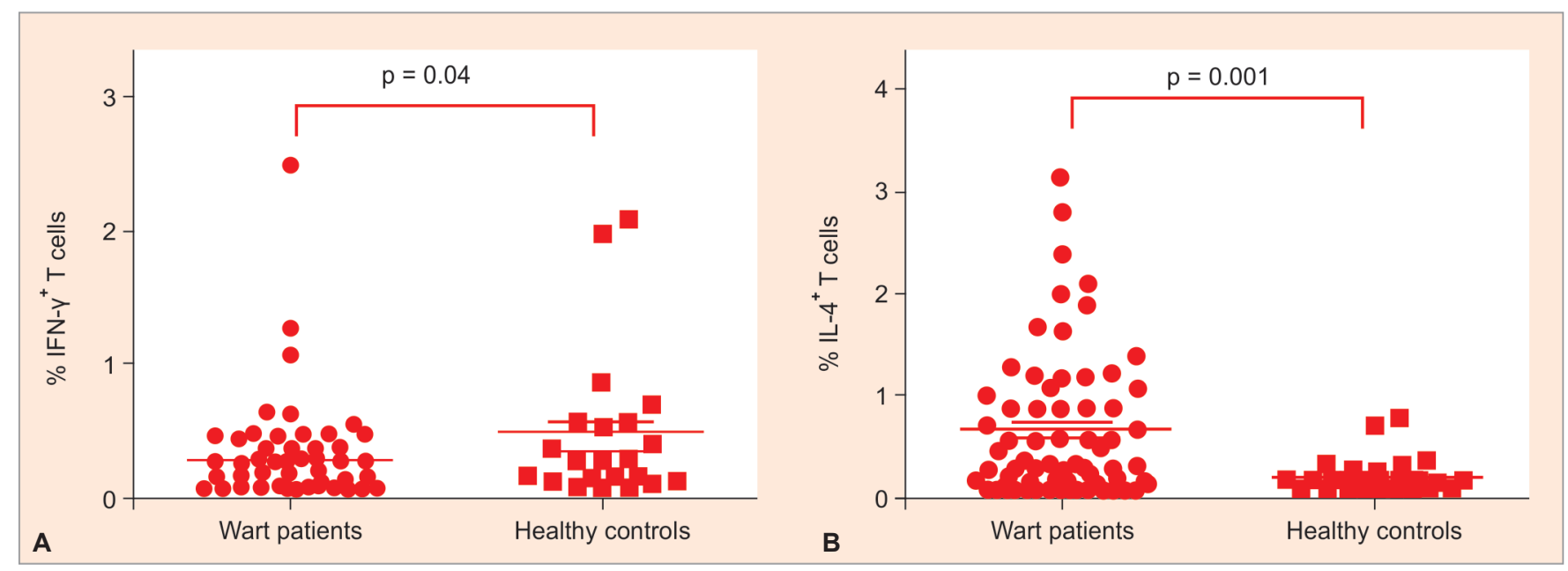

Graphs 2A and B: T-cell response against HPV-11 peptide in wart patients and HCs. Data are shown as scatter plot of percent frequency and mean of (A) CD3+IFN- $\square+$ T cells and (B) CD3+IL-4+ T cells

\section{DISCUSSION}

Appearance of warts associated with suppression of cell-mediated immunity (decreased Th1 and increased Th2 response) has been reported in HPV-6 and/or -11-infected patients. ${ }^{18,19}$ To the best of our knowledge, till date, no study has been initiated or done on the role of HPV antigen-specific immune response in subjects with anogenital warts (SSs) due to highly localized nature, lack of significant systemic manifestations of the infection, and social taboo. Here, we have demonstrated HPV antigen-specific functional skewing of protective (Th1) vs suppressive (Th2) immune response in peripheral blood from subjects with warts (SSs). Earlier studies had demonstrated virus-specific antibodies in the sera of genital wart patients. ${ }^{20}$ However, Almeida et $\mathrm{al}^{21}$ had demonstrated that sera from genital wart patients specifically reacted with virus from genital warts only and not with that from skin warts unlike sera from skin wart patients which reacted with both types of viruses.
The seroconversion of 27.6 to $75 \%$ following skin test, specifically in patients testing positive (36.9-86.6\%), supported presence of low levels of antibodies specific to wart virus in many cases. Several studies had attempted to understand the role of host T-cell immune response against HPVs, specifically cell-mediated immunity. The supporting role of cell-mediated immunity in controlling $\mathrm{HPV}$ infection is evident in many reviews of literature, which has documented that prevalence of HPV infection and associated disease is increased in immunosuppressed populations. Another study showed HPV infection in all immunosuppressed women presenting with neoplasia of lower genital tract. ${ }^{22}$ In the 1990 s, as the diagnosis of HPV infection by molecular diagnosis was developed, there were many reports confirming the rise in the incidence of infection with $\mathrm{HPV}^{23}$ and other comorbidities, which included warts ${ }^{24}$ and cervical squamous intraepithelial lesions ${ }^{25}$ in patients who were immunosuppressed. The association of reduced cell-mediated immunity and 
consequent increase in HPV infection and associated disease in HIV-infected individuals has been demonstrated in various studies wherein these patients have shown increased prevalence ${ }^{26-31}$ and longer period of persistence of HPV infection, ${ }^{26,32-35}$ which also provides a strong evidence to support the role of cell-mediated immunity. One of the major limitations in studies of cellmediated immune responses to HPV infection due to its highly localized nature of tissue tropism is squamous epithelial sites. Therefore, it is challenging to demonstrate HPV-specific cell-mediated immune responses in peripheral blood of wart patients. Studies had reported the evidence of the role of IFN- $\square$, TGF- $\square$, and tumor necrosis factor in inhibition of HPV-infected cell growth, and persistence of viral infection and progression of disease could be due to escape from these mechanisms. As the epithelial cells have shown to be the producers of these cytokines except for IFN- $\square$, some authors have suggested the autocrine role of cytokines in growth regulation of keratinocytes infected with HPV. ${ }^{36-38}$ This points to the fact that a large number of cell types possibly are contributing to the growth-inhibitory function; these cytokines are secreted by many cells like T cells, macrophages, NK cells, and others. Cell-mediated immunity to HPV had been studied by in vitro tests, ${ }^{39,40}$ but there is much controversy regarding the significance of these tests, ${ }^{41}$ and, in general, patients with anogenital warts were excluded from these studies. ${ }^{39}$ Moreover, there is scarcity of data on HPV-6 and -11 peptide-specific cell-mediated immune responses in peripheral blood of genital wart patients. In our study, we investigated the HPV-6 and - 11 antigen-specific T cellmediated immune responses in PBMCs in patients with warts. Our observation of incidence of reduced frequency of HPV-specific IFN- $\square$ T-cell responders in peripheral blood is consistent with the earlier studies conducted in localized warts. In contrast, increased frequency of HPV antigen-specific IL-4-producing T cells observed in peripheral blood of wart patients suggested that genital warts induced a systemic immune suppression in the host. Cell-mediated immunity plays a major role in the cure of skin warts. ${ }^{42}$ Our results are consistent with other studies and strengthen the evidences pointing to the role of HPV-specific host T-cell immune response in warts. ${ }^{43}$

\section{CONCLUSION}

Our study demonstrated strong association of anogenital warts with Th2 skewed peripheral T-cell response. Our findings warrant future investigations to design specifically targeted, effective immune-prophylactic and immune-therapeutic strategies against HPV-induced lesions of the genital tract, which might lead to early clearance and prevention of relapse.

\section{CLINICAL SIGNIFICANCE}

The study findings may be helpful in designing future immunomodulation strategies for venereal wart patients, specifically for management of recurrence after standard treatment. Such approach might pave way for potential adjunct therapy with immunomodulators to augment host immune response.

\section{ACKNOWLEDGMENT}

The authors would like to acknowledge the valuable contributions of Professor PK Sharma, Head, Department of Dermatology and Venereology, all residents especially Dr Neha, from the Department of Dermatology, Dr RML Hospital, New Delhi, Mr NP Singh, Pankaj, Arvind, Lab Technicians, Abhinav Saurabh, Prabin, Divya, Girija, Manju, SRF, Department of Transplant Immunology and Immunogenetics, All India Institute of Medical Sciences. Special thanks to Dr. V Sreenivas, Professor, Department of Biostatistics, AIIMS, New Delhi for help with the statistical analysis.

\section{REFERENCES}

1. Narayanan B. A retrospective study of the pattern of sexually transmitted diseases during a ten-year period. Indian J Dermatol Venereol Leprol 2005 Sep-Oct;71(5):333-337.

2. Milner, DA. Diagnostic pathology: infectious diseases. Philadelphia (PA): Elsevier Health Sciences; 2015. p. 40.

3. Greer CE, Wheeler CM, Ladner MB, Beutner K, Coyne MY, Liang H, Langenberg A, Yen TS, Ralston R. Human papillomavirus (HPV) type distribution and serological response to HPV type 6 virus-like particles in patients with genital warts. J Clin Microbiol 1995 Aug;33(8):2058-2063.

4. Gross G, Pfister H. Role of human papillomavirus in penile cancer, penile intraepithelial squamous cell neoplasias and in genital warts. Med Microbiol Immunol (Berl) 2004 Feb;193(1):35-44.

5. Insinga RP, Dasbach EJ, Myers ER. The health and economic burden of genital warts in a set of private health plans in the United States. Clin Infect Dis 2003 Jun;36(11):1397-1403.

6. Castellsague X, Ghaffari A, Daniel RW, Bosch FX, Muňoz N, Shah KV. Prevalence of penile human papillomavirus DNA in husbands of women with and without cervical neoplasia: a study in Spain and Colombia. J Infect Dis 1997 Aug;176(2):353-361.

7. Colón-López V, Ortiz AP, Palefsky J. Burden of human papillomavirus infection and related co-morbidities in men: implications for research, disease prevention and health promotion among Hispanic men. P R Health Sci J 2010 Sep;29(3):232-240.

8. Partridge JM, Hughes JP, Feng Q, Winer RL, Weaver BA, Xi LF, Stern ME, Lee SK, O'Reilly SF, Hawes SE, Kiviat NB, Koutsky LA. Genital human papillomavirus infection in men: incidence and risk factors in a cohort of university students. J Infect Dis 2007 Oct;196(8):1128-1136.

9. Kacerovska D, Pizinger K, Kumpova M, Cetkovska P. Genital warts treated by photodynamic therapy. Skinmed 2007 NovDec;6(6):295-297.

10. Stanley M. Immunobiology of HPV and HPV vaccines. Gynecol Oncol 2008 May;109(2 Suppl):S15-S21. 
11. Amador-Molina A, Hernández-Valencia JF, Lamoyi E, Contreras-Paredes A, Lizano M. Role of innate immunity against human papillomavirus (HPV) infections and effect of adjuvants in promoting specific immune response. Viruses 2013 Nov;5(11):2624-2642.

12. Sasagawa $\mathrm{T}$, Takagi $\mathrm{H}$, Makinoda $\mathrm{S}$. Immune response against human papillomavirus (HPV) infection and evasion of host defense in cervical cancer. J Infect Chemother 2012 Dec;18(6): 807-815.

13. Morelli AE, Belardi G, DiPaola G, Paredes A, Fainboim L. Cellular subsets and epithelial ICAM-1 and HLA-DR expression in human papillomavirus infection of the vulva. Acta Derm Venereol 1994 Jan;74(1):45-50.

14. Feng JY, Peng ZH, Tang XP, Geng SM, Liu YP. Immunohistochemical and ultrastructural features of Langerhans cells in condyloma acuminatum. J Cutan Pathol 2008 Jan; 35(1): 15-20.

15. DeVoti J, Hatam L, Lucs A, Afzal A, Abramson A, Steinberg B, Bonagura V. Decreased Langerhans cell responses to IL-36 $\square$ : altered innate immunity in patients with recurrent respiratory papillomatosis. Mol Med 2014 Aug;20:372-380.

16. Cao Y, Zhao J, Lei Z, Shen S, Liu C, Li D, Liu J, Shen GX, Zhang GM, Feng ZH, Huang B. Local accumulation of FOXP3+ regulatory $\mathrm{T}$ cells: evidence for an immune evasion mechanism in patients with large condylomata acuminate. J Immunol 2008 Jun;180(11):7681-7686.

17. Al-Saeed IAM, Al-Saadi MAK, Ewadh WAA, College of Medicine, Babylon University. Immunological study on genital wart patients in Babylon Province - Iraq. Med J Babylon 2015 May;12(1):233-239.

18. Clerici M, Merola M, Ferrario E, Trabattoni D, Villa ML, Stefanon B, Venzon DJ, Shearer GM, De Palo G, Clerici E. Cytokine production patterns in cervical intraepithelial neoplasia: association with human papillomavirus infection. J Natl Cancer Inst 1997 Feb;89(3):245-250.

19. Peghini BC, Abdalla DR, Barcelos AC, Teodoro Ld, Murta EF, Michelin MA. Local cytokine profiles of patients with cervical intraepithelial and invasive neoplasia. Hum Immunol 2012 Sep;73(9):920-926.

20. Ogilvie MM. Serological studies with human papova (wart) virus. J Hyg (Lond) 1970 Sep;68(3):479-490.

21. Almeida JD, Oriel JD, Stannard LM. Characterisation of the virus found in human genital warts. Microbios 1969;3:225-233.

22. Sillman F, Stanek A, Sedlis A, Rosenthal J, Lanks KW, Buchhagen D, Nicastri A, Boyce J. The relationship between human papillomavirus and lower genital intraepithelial neoplasia in immunosuppressed women. Am J Obstet Gynecol 1984 Oct;150(3):300-308.

23. Fairley CK, Chen S, Tabrizi SN, McNeil J, Becker G, Walker R, Atkins RC, Thomson N, Allan P, Woodburn C, et al. Prevalence of HPV DNA in cervical specimens in women with renal transplants: a comparison with dialysis-dependent patients and patients with renal impairment. Nephrol Dial Transplant 1994 Jan;9(4):416-420.

24. Leigh IM, Glover MT. Skin cancer and warts in immunosuppressed renal transplant recipients. Recent Results Cancer Res 1995 Feb;139:69-86.

25. Ozsaran AA, Ateş T, Dikmen Y, Zeytinoglu A, Terek C, Erhan Y, Ozacar T, Bilgiç A. Evaluation of the risk of cervical intraepithelial neoplasia and human papilloma virus infection in renal transplant patients receiving immunosuppressive therapy. Eur J Gynaecol Oncol 1999; 20(2):127-130.
26. Critchlow CW, Hawes SE, Kuypers JM, Goldbaum GM, Holmes KK, Surawicz CM, Kiviat NB. Effect of HIV infection on the natural history of anal human papillomavirus infection. AIDS 1998 Jul;12(10):1177-1184.

27. Critchlow CW, Holmes KK, Wood R, Krueger L, Dunphy C, Vernon DA, Daling JR, Kiviat NB. Association of human immunodeficiency virus and anal human papillomavirus infection among homosexual men. Arch Intern Med 1992 Aug;152(8):1673-1676.

28. Hillemanns P, Ellerbrock TV, McPhillips S, Dole P, Alperstein S, Johnson D, Sun XW, Chiasson MA, Wright TC Jr. Prevalence of anal human papillomavirus infection and anal cytologic abnormalities in HIV-seropositive women. AIDS 1996 Dec;10(14):1641-1647.

29. Palefsky JM, Gonzales J, Greenblatt RM, Ahn DK, Hollander H. Anal intraepithelial neoplasia and anal papillomavirus infection among homosexual males with group IV HIV disease. JAMA 1990 Jun;263(21):2911-2916.

30. Palefsky JM, Holly EA, Ralston ML, Arthur SP, Hogeboom CJ, Darragh TM. Anal cytological abnormalities and anal HPV infection in men with Centers for Disease Control group IV HIV disease. Genitourin Med 1997 Jun;73(3):174-180.

31. Palefsky JM, Holly EA, Ralston ML, Jay N. Prevalence and risk factors for human papillomavirus infection of the anal canal in human immunodeficiency virus (HIV)-positive and HIV-negative homosexual men. J Infect Dis 1998 Feb;177(2): 361-367.

32. Del Mistro A, Insacco E, Cinel A, Bonaldi L, Minucci D, Chieco-Bianchi L. Human papillomavirus infections of the genital region in human immunodeficiency virus seropositive women: integration of type 16 correlates with rapid progression. Eur J Gynaecol Oncol 1994 Jan;15(1):50-58.

33. Eckert LO, Watts DH, Koutsky LA, Hawes SE, Stevens CE, Kuypers J, Kiviat NB. A matched prospective study of human immunodeficiency virus serostatus, human papillomavirus DNA, and cervical lesions detected by cytology and colposcopy. Infect Dis Obstet Gynecol 1999 Jan;7(3):158-164.

34. Minkoff H, Feldman J, DeHovitz J, Landesman S, Burk R. A longitudinal study of human papillomavirus carriage in human immunodeficiency virus-infected and human immunodeficiency virus-uninfected women. Am J Obstet Gynecol 1998 May;178(5):982-986.

35. Sun X-W, Kuhn L, Ellerbrock TV, Chiasson MA, Bush TJ, Wright TC Jr. Human papillomavirus infection in women infected with the human immunodeficiency virus. N Engl J Med 1997 Nov;337(19):1343-1349.

36. Malejczyk J, Malejczyk M, Köck A, Urbanski A, Majewski S, Hunzelmann N, Jablonska S, Orth G, Luger TA. Autocrine growth limitation of human papillomavirus type 16-harboring keratinocytes by constitutively released tumor necrosis factor-alpha. J Immunol 1992 Oct;149(8):2702-2708.

37. Malejczyk J, Malejczyk M, Majewski S, Breitburd F, Luger TA, Jablonska S, Orth G. Increased tumorigenicity of human keratinocytes harboring human papillomavirus type 16 is associated with resistance to endogenous tumor necrosis factor-alpha-mediated growth limitation. Int J Cancer 1994 Feb;56(4):593-598.

38. Woodworth CD, Notario V, DiPaolo JA. Transforming growth factors beta 1 and 2 transcriptionally regulate human papillomavirus (HPV) type 16 early gene expression in HPVimmortalized human genital epithelial cells. J Virol 1990 Oct;64(10):4767-4775. 
39. Morison WL. In vitro assay of cell-mediated immunity to human wart antigen. Br J Dermatol 1974 May;90(5): 531-534.

40. Ivanyi L, Morison WL. In vitro lymphocyte stimulation by wart antigen in man. Br J Dermatol 1976 May;94(5):523-527.

41. Lee AK, Eisinger M. Cell-mediated immunity (CMI) to human wart virus and wart-associated tissue antigens. Clin Exp Immunol 1976 Dec;26(3):419-424.
42. Viac J, Thivolet J, Chardonnet Y. Specific immunity in patients suffering from recurring warts before and after repetitive intradermal tests with human papilloma virus. Br J Dermatol 1997 Oct; $97(4): 365-370$.

43. Viac J, Thivolet J, Hegazy MR, Chardonnet Y, Dambuyant C. A comparative study of delayed hypersensitivity skin reactions and antibodies to human papilloma virus (HPV). Clin Exp Immunol 1997 Aug;29(2):240-246. 